\title{
Assessment of Dairy Product Safety Supervision in Sales Link: A Fuzzy-ANP Comprehensive Evaluation Method
}

\author{
Tingqiang Chen $\mathbb{D}$, Shuaibin Wang $\mathbb{D}$, Lei Pei, and Jining Wang $\mathbb{C}$ \\ School of Economic and Management, Nanjing Tech University, Nanjing 211816, China \\ Correspondence should be addressed to Jining Wang; wangjn163@126.com
}

Received 6 February 2018; Revised 3 April 2018; Accepted 9 May 2018; Published 25 June 2018

Academic Editor: Amy Simonne

Copyright (c) 2018 Tingqiang Chen et al. This is an open access article distributed under the Creative Commons Attribution License, which permits unrestricted use, distribution, and reproduction in any medium, provided the original work is properly cited.

\begin{abstract}
An evaluation index system is developed to assess food safety supervision in the sales links of dairy products. Evaluation research is conducted using the fuzzy-ANP comprehensive evaluation model to assess the product safety supervision of dairy products in the sales link based on 307,705 survey data acquired from 1,501 online and offline dairy businesses in China. Evaluation results show that (1) the overall situation of dairy product safety supervision in the sales link is encumbered by the fact that the online situation of dairy product safety supervision in the sales link is general. It does not achieve a relatively good level; (2) the investment in food safety supervision of dairy products in the sales link is insufficient for the online e-commerce platforms. Especially, the processes of reviewing and approving relevant business sales qualification must be improved; (3) online business types do not directly determine the situation of dairy product safety supervision in the sales link, but the operating environment, sales staff quality, and warehousing management are common regulatory weaknesses; and (4) for offline provinces, the level of economic development can affect the situation of dairy product safety supervision in the sales link. Aside from emphasizing sales qualifications, economically backward provinces should improve the supervision of the operating environment, sales equipment, sanitary status of workers, and other aspects.
\end{abstract}

\section{Introduction}

Food safety is a vital public interest, and it has been a problem that received increased attention in the social development process. Food safety management involves extensive professional knowledge in food science; thus, a single government regulation model fails to satisfy the consumer demand for safe food [1]. Moreover, the government is and will be playing a major role in ensuring the security of the food supply chain due to the administrative authority and legal implications of government regulations. Government regulations can positively affect the upstream and downstream of a supply chain in the food supply chain security protection [2] and are helpful to address security issues in the food market that are attributed to information asymmetry [3], thereby reducing food safety hazards.

Current studies on food safety risk management mainly focus on the security risk sources and performance. And these studies cause to propose countermeasures and suggestions, including strengthening government regulations and establishing a food traceability system for security risks of food supply chains. For example, Jones et al. [4], Fulponi [5], and $\mathrm{Xu}$ and $\mathrm{Wu}[6]$ determined that an imperfect food traceability system is an important factor for continuous food safety incidents. Strengthening the construction of the food traceability system helps to restore the confidence of the food consumers. Darby and Karni [7], Starbird [8], and Wang et al. [9] attributed the occurrence of the "moral hazard" to information asymmetry in the food market. The role of government regulations is crucial to improve food safety. Frewer et al. [10], Rosati and Saba [11], and Liu et al. [12] suggested that food-related hazards are mainly reflected in counterfeit food, inferior food, deteriorated food, food containing pesticides, and so on. Government regulations and service can reduce them. Hinrichs [13], Pei et al. [14], and Chen et al. [15] found that government regulations and 
service are helpful to reduce the hidden dangers of food safety. However, studies on external regulations that affect food safety risks are few. Thus, the literature that evaluates food safety supervision in China is limited.

In addition, some scholars generally believed that food safety risks are contagious and are mainly attributed to the upstream side of the supply chain now. For example, Silbergeld et al. [16], Doyle [17], Hu and Cheng [18], and Boxstael et al. [19] posited that wide food safety concerns come from food production. Zhou et al. [20] and Rodrigues et al. [21] found that the existence of hidden danger in agricultural production is the main reason why food safety events happened. Chan and Lai [22] determined that food safety problems are rooted in food production and particularly reflected on the low virtues of food producers. There are few researches on the safety supervision in sales link, which is the last line of defense for protecting consumers' rights and interests. The food sales link is a link that the market department of a food manufacturer, commodity retail enterprise, food retailer, and so on provides food directly to consumers through different sales channels (online sales or offline sales). It is located at the terminal of food circulation and is the final gateway for food circulation. China must urgently evaluate and analyze food safety supervision in the sales link to reduce food safety hazards.

Accidents related to safety in the dairy industry, such as "Big head baby milk powder" and "Milk powder with melamine" seriously reduced consumers confidence in the safety of dairy products $[14,23]$. At the same time, they also aroused public suspicion of government efforts on food safety supervision and were testing government capacity and credibility $[5,24]$. In addition, with the rapid development of e-commerce in China, the market potential of the online sales for dairy products is being constantly highlighted. In addition, dairy businesses have pioneered online sales channels, combining online and offline channels for product sales. The so-called online sales channel is that dairy businesses rely on Taobao, Jingdong, Suning, and other e-commerce platforms to conduct online transactions. Similar to traditional sales, offline sales channels refer to dairy businesses mainly adopting store management methods to conduct face-to-face transactions. Therefore, evaluating the situation of dairy product safety supervision in the sales link is crucial to improve the supervision of dairy products, regulate the sales behavior of online and offline dairy businesses, and reduce safety risks.

In light of the above considerations, this study constructed an index system for food safety supervision in the sales link of dairy products based on the analysis of China's food safety laws and the existing literature. Based on 307,705 data from 1,501 various online and offline dairy businesses, evaluating food safety supervision in the sales link was conducted from four prospects: sales channels, e-commerce platforms, business types, and provinces with a fuzzy-ANP comprehensive evaluation model.

The rest of the paper is organized as follows: Section 2 describes the index system of the safety supervision of dairy products. Section 3 presents the fuzzy-ANP comprehensive evaluation model. An empirical research based on 1,501 questionnaires and 307,705 data from various online and offline dairy businesses, three e-commerce platforms, three types of online businesses, and three offline provinces are discussed in Section 4. Section 5 analyzes the results of the empirical study. Section 6 discusses the results of the study and puts forward recommendations. Finally, Section 7 summarizes and elaborates the conclusions of the study.

\section{Construction of an Evaluation Index System}

Loopholes exist in the transparency of food supply chain links because the food traceability system construction is imperfect in China; thus, lemon problems in the food market remain unsolved [25]. Facing the fact that the existing system is limited to a certain degree, hence, consumers prefer stringent food supply chain safety regulations. $\mathrm{Nu}-$ merous unscrupulous manufacturers reduce sales cost to meet the consumer demand and to profit by maximizing their own interests and consumer utility. As a result, security risks flow to the market, seriously affecting food safety in China. Hence, the index system for food safety supervision in the sales link mainly considered "hardware" and "software" costs.

2.1. Sales Conditions and Technologies. Chapter IV, Section 1, Article 1 of the new "Food Safety Law" specifies the safety standard in food production and operation that must be met. Food producers and operators are required to have clean and safe business locations. Disinfection and anticorrosion must be applied, and other facilities must be adapted to the number of operating varieties; furthermore, the reasonable hygienic equipment layout and the use of clean nontoxic packaging materials are also necessary. We summarize the above requirements and conclude that food businesses require conditions and technologies. The conditions and technical conditions of food sales are mainly examined based on three aspects.

2.1.1. Sales Equipment. Seafood, dairy, and other types of food can achieve their theoretical shelf lives only when storage environments meet corresponding conditions. If any link in the entire food supply chain fails, it creates conditions conducive to the growth of microorganisms, reducing the shelf life of food [26]. Therefore, sales terminals must also be equipped with appropriate refrigeration facilities, ventilation equipment, and so on, in order to create a storage environment that meets food requirements. According to the existing research results and the "Food Safety Law," sales equipment should be subdivided into four indexes to evaluate sales conditions and technologies; these indexes include the temperature ranges that facilities can be set to, the frequency of equipment being checked and maintained, the complete degree of sales equipment, and hygienic qualification rate of equipment [27-31].

2.1.2. Packaging Materials. The present situation of food packaging safety in China is not optimistic. Problems such as 
improper use of prohibited additives in packaging materials, excessive content of heavy metals in packaging products, and illegal use of poisonous and harmful packing materials are in great numbers [32]. Packaging materials come in direct contact with food, thereby preventing contamination and reducing possible mold and yeasts. But raw materials and processes can directly influence food safety. Substandard packaging materials cause secondary contamination to food, which affects the health of consumers [33]. Packaging materials, which are a component of the final step before selling food products, are a crucial factor of food safety [34]. According to the existing research results and the "Food Safety Law," packaging materials should be categorized into three indexes to evaluate sales conditions and technologies; these indexes include the hygienic qualification rate of packaging materials, the qualification rate of packaging materials, and the independent package rate of food in bulk [35-38].

2.1.3. Operating Environment. In the entire food supply chain system, the sales terminal is the last stop before food reaches consumers. Storage location, hygiene, rationality of layout, and other factors influence the rate of spoilage of food, may result in cross-contamination, and affect food safety indirectly. Substandard operating environments are common, particularly in small- and medium-sized shops [39]. According to the existing research results and "Food Safety Law," packaging materials should be categorized into six indexes to evaluate sales conditions and technologies; these indexes include the coverage of lighting facilities, the rationale of the business layout, the frequency of sanitation check in the place of business, the disinfection facilities in the place of business, the qualification rate of the sales condition in business places, and the frequency of garbage disposal [40-45].

2.2. Sales Management. Besides the safety standards for "hardware" facilities of food production and management, the new "Food Safety Law" clarified "software" service standards. Article 35 requires food production operators to obtain relevant qualifications; Articles 33, 44, and 45 stipulate the hygiene requirements that food producers and operators must achieve; Articles 68 and 72 prescribe the contents of the food information to be published. Sales qualification, sales personnel competencies/skills/education, and the food information to display can be discussed based on the definition of sales management and according to the Food Safety Law.

2.2.1. Sales Qualification. China implements a licensing system for food businesses to prevent and reduce food safety accidents and to protect the lives and health of citizens. To a certain degree, this system reduces the participation of food operators in the sales link whose sales conditions and environment are substandard and improves food safety from the source. Furthermore, possessing a food sales qualification proves that operators meet the legal requirements pertaining relevant qualifications and abilities, easing the "lemons problem" on the food market to a certain extent [46]. According to related laws, sales qualification should be categorized into three indexes to evaluate sales management, namely, food business, food circulation, and business licenses [47-49].

\subsubsection{Sales Personnel Competencies/Skills/Education. As an} important participant in the food circulation process, sales personnel significantly influence food safety. Sales personnel are responsible for removing expired food and placing food warning signs. In selling bulk food such as fresh and baked goods, sales personnel are in direct contact with food and package food. Therefore, the qualities of sales personnel must be improved by conducting food safety knowledge training [50]. These methods can reduce the possibility of secondary contamination of food and food safety risks caused by wrong practices of sales personnel. According to the existing research results and "Food Safety Law," sales personnel competencies/skills/education should be categorized into eight indexes to evaluate sales management; these indexes include the completeness of workbooks, the health certificate of the operators, the frequency of regular physical examination of the operator, the sanitation status before operations, the frequency of regular training on food safety knowledge and technology, contamination caused by operators, the moral level of operators, and equipment of the food safety management staff $[44,50-55]$.

2.2.3. Food Information Display. Food-related information appeared on labels is important for consumers. On the one hand, information appeared on labels can provide basis for consumers to assess food safety. On the other hand, it can alleviate the "information asymmetry" problem in the food industry to a certain degree $[7,56]$. According to the existing research results and "Food Safety Law," food information display should be categorized into four indexes to evaluate sales management; these indexes include the completeness and authenticity of food specific information, the completeness and authenticity of Chinese information for food imports, the standard compliant of related logos of bulk food, and the criteria situation of food warnings and precautions [57-61].

2.3. Storage Facilities Management. Storage facilities reflect the status of factory material activities, and they are the transfer stations of supply and sales. Presale storage facilities management must be reinforced to ensure that food is fresh without security risks, such as mold and yeasts, spoilage, and those they do not threaten the health of consumers when food reaches them. An efficient and reasonable food storage management system helps provide a visual display of all kinds of information and complete the work of monitoring and tracing food, which can improve food safety in China [62]. Therefore, warehousing management is evaluated from the following aspects.

2.3.1. Inventory Management. In the food industry, the importance of inventory management is reflected in cost control, as well as on its effect on food safety. On the one hand, food has a fixed shelf life or optimum edible period. Inventory backlog occurs if dealers purchase a large amount of food in one time. 
As a result, the validity period of food shortens or taste is poor when food eventually reaches consumers and food safety hazards frequently occur. On the other hand, when food safety accidents occur, the inventory files of stored food and the delivering cargo from storage are helpful to recall "problem foods" to minimize harm. According to the existing research results and "Food Safety Law," inventory management should be classified into three indexes to evaluate storage facilities management; these indexes include the satisfaction of first-in and first-out (FIFO), the frequency of regular quality and quantity checks of inventory food, and the purchase file and inspection records [63-66].

2.3.2. Quality Preservation. In the past, antiseptic and other food additives are included in the production link to prolong the shelf life of food. Adjusting storage environments and their related physical indicators to preserve food quality is being preferred by the food retail sector because the effect of the long-term use of chemical additives is uncertain now [67]. However, many markets' partial storage environmental indicators are still substandard [67], and consumer health is threatened. According to the existing research results and "Food Safety Law," quality preservation should be classified into five indexes to evaluate storage facilities management; these indexes include the timely disposal of expired and deteriorated food, storage equipment of different packaged food, the food storage division, the temperature control range, and the satisfactory lighting conditions [30, 55, 68-71].

2.4. Sales Security Management. Reinforcing the safety management of food sales is a crucial component of the supply chain and a vital part of reducing food safety incidents in the sales link and enhancing food safety in China. According to the existing research results and "Food Safety Law," sales security management should be classified into five indexes; these indexes include the legality of the content of food marketing advertisements, the sales situation of banning food by law, the situation that proactively offers consumers sales documents, the establishment of food delisting system for sales, and the ability to handle food safety incidents for sale units $[14,72-76]$.

An index system for food safety supervision of dairy products is developed based on the above analysis of the factors that affect the safety of food in the sales link, which is combined with expert opinions using the Delphi method. The Delphi expert group consists of 11 experts, which include six food safety management professors from colleges and universities, two experts and engineers from a government food safety regulatory department, one food safety media expert, one consumer association expert, and one food business expert. The constructed system is shown in Table 1.

\section{Evaluation Model}

3.1. The ANP-Fuzzy Comprehensive Evaluation Model. The ANP-fuzzy comprehensive evaluation model is composed of the analytic network process (ANP) and fuzzy comprehensive evaluation method. On the one hand, the ANP can describe the interrelationship between objects because the simple hierarchical structure of the analytic hierarchy process is dynamic, and the interrelationship among the elements is combined with the network structure within the system [77]. On the other hand, the fuzzy comprehensive evaluation method based on the membership theory of fuzzy mathematics can effectively evaluate qualitative indexes [78].

In evaluating the situation of food safety supervision in the sales link, the assessment of similar foods had a hierarchical structure, and the evaluation of different foods exhibited a dependent relationship. A few indexes could not be directly quantified for their intervals and fuzzy characteristics on certain values. Thus, general evaluation methods could not accurately and objectively evaluate the situation of food safety supervision in the sales link. Therefore, an assessment matrix was developed by expert scoring. The weight of each evaluation index was then calculated by the ANP analysis. The fuzzy comprehensive evaluation method was combined, and the food safety supervision in the sales link was finally evaluated.

\subsection{The Construction Steps of the ANP-Fuzzy Comprehensive Evaluation Model}

Step 1. We constructed the network structure of the ANP. The network structure of the situation of food safety supervision in the sales link had three layers, which included the control, network, and object layers. In the network structure, the control layer contained the target and criteria; the target was $A$, and the criteria were the first-level indexes of the index system, including $B_{1}, B_{2}, B_{3}$, and $B_{4}$. The network layer included nine sets of elements correspond to the second- and third-level indexes of the index system; these sets were $C_{1}, C_{2}, C_{3}, C_{4}, C_{5}, C_{6}, C_{7}, C_{8}$, and $C_{9}$. The network structure of the ANP, as shown in Figure 1, was constructed according to the mutual influence relationship within the evaluation index set of elements and between the set of elements and the indexes.

Step 2. We calculated a supermatrix and weighted supermatrix. Supposed that the ANP control layer criterion contains the first-level index $B_{i}(i=1,2, \ldots, m)$, the network layer contained the second-level index $C_{s}(s=1,2, \ldots, n)$, and $C_{j}$ contained the third-level index $C_{j 1}, C_{j 2}, \ldots$, $C_{j k}(j=1,2, \ldots, n ; k=1,2, \ldots, n)$. In the index system for the situation of food safety supervision in the sales link, according to the criterion of the first-level index $B_{i}$, the interaction between the secondary indexes was determined. Then on the basis of it, we constructed the judgment matrix and obtained the feature vector $\left(w_{1 j}, w_{2 j}, \ldots, w_{i j}\right)$. Furthermore, we tested the consistency of the feature vector and got a local weight vector matrix $W_{i j}$. Thus, the supermatrix $W$ could be formed under the first-level index $B_{i}$, but $W$ was not a normalization matrix. In the matrix, each element represented 1 matrix, and the sum of the columns was 1 , as shown in (1). Multiply the supermatrix 
TABLE 1: Index system for the situation of food safety supervision in the sales link.

\begin{tabular}{c}
\hline Objective \\
\hline \\
\\
\\
\\
Sales conditions and \\
technology $\left(B_{1}\right)$
\end{tabular}

Packaging materials $\left(C_{2}\right)$ technology $\left(B_{1}\right)$

The situation of food safety supervision in sales link (A)

Second-level index
Sales equipment $\left(C_{1}\right)$
Packaging materials $\left(C_{2}\right)$
Operating environment $\left(C_{3}\right)$

Sales qualification $\left(C_{4}\right)$

Sales personnel competencies/skills/education $\left(C_{5}\right)$

Sales management $\left(B_{2}\right)$
Temperature range that facilities can be set $\left(C_{11}\right)$

Frequency of equipment being checked and maintained $\left(C_{12}\right)$

Complete degree of sales equipment $\left(C_{13}\right)$

Hygienic qualification rate of equipment $\left(C_{14}\right)$

Hygienic qualification rate of packaging materials $\left(C_{21}\right)$

Qualification rate of packaging materials $\left(C_{22}\right)$

Independent package rate of food in bulk $\left(C_{23}\right)$

Coverage of lighting facilities $\left(C_{31}\right)$

Layout rationality of business places $\left(C_{32}\right)$

Frequency of sanitation being checked and cleaned in the place of business $\left(C_{33}\right)$

Equipment of disinfection facilities in the place of business $\left(C_{34}\right)$

Qualification rate of sales

condition in business places $\left(C_{35}\right)$

Frequency of garbage being disposed $\left(C_{36}\right)$

Food business license $\left(C_{41}\right)$ Food circulation license $\left(C_{42}\right)$ Business license $\left(C_{43}\right)$

Completeness of workbook $\left(C_{51}\right)$ Health certificate of operators $\left(C_{52}\right)$ Frequency of regular physical examination of operators $\left(C_{53}\right)$

Sanitation status before operations $\left(C_{54}\right)$

Frequency of regular training of food safety knowledge and technology $\left(C_{55}\right)$

Contamination caused by operators $\left(C_{56}\right)$

Moral level of the operators $\left(C_{57}\right)$ Equipment of food safety management staff $\left(C_{58}\right)$

Completeness and authenticity of food specific information $\left(C_{61}\right)$

Completeness and authenticity of

Chinese information for food imports $\left(C_{62}\right)$

Food information display $\left(C_{6}\right)$
Standard compliant of related logo of bulk food $\left(C_{63}\right)$

Criteria situation of food warnings and precautions $\left(C_{64}\right)$ 
TABle 1: Continued.

\begin{tabular}{|c|c|c|c|}
\hline Objective & First-level index & Second-level index & Third-level index \\
\hline & $\begin{array}{l}\text { Storage facilities } \\
\text { management }\left(B_{3}\right)\end{array}$ & 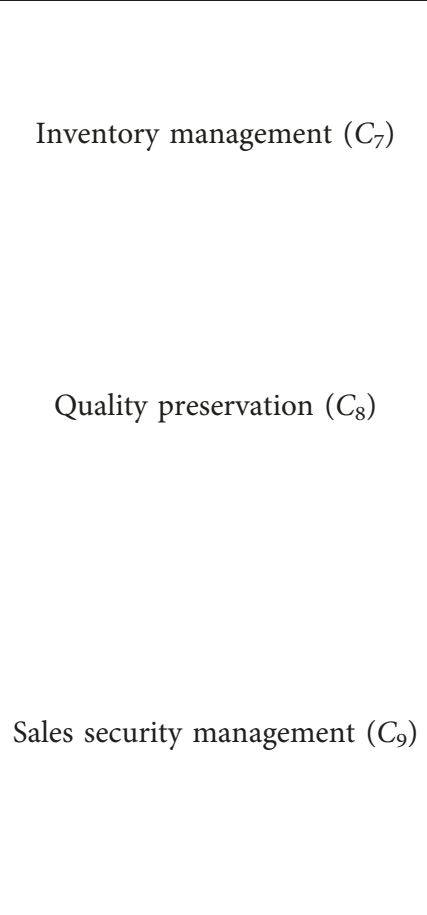 & $\begin{array}{l}\text { Satisfaction of first-in and first-out } \\
\qquad\left(C_{71}\right) \\
\text { Frequency of inventory food's } \\
\text { quality and quantity being checked } \\
\text { regularly }\left(C_{72}\right) \\
\text { Establishment of purchase file and } \\
\text { inspection records }\left(C_{73}\right) \\
\text { Timely disposal of expired and } \\
\left.\text { deteriorated food ( } C_{81}\right) \\
\text { Storage equipment of different } \\
\text { packaged foods }\left(C_{82}\right) \\
\text { Food storage division }\left(C_{83}\right) \\
\text { Temperature control range }\left(C_{84}\right) \\
\text { Satisfaction of lighting conditions } \\
\quad\left(C_{85}\right) \\
\text { Legality of the content of the food } \\
\left.\text { marketing ad ( } C_{91}\right) \\
\text { Sales situation of banning food by } \\
\text { law }\left(C_{92}\right) \\
\text { Situation that proactively offers } \\
\text { consumers sales documents }\left(C_{93}\right) \\
\text { Establishment of the food delisting } \\
\text { system for sales unit }\left(C_{94}\right) \\
\text { Ability to handle food safety } \\
\text { incidents for sales unit }\left(C_{95}\right)\end{array}$ \\
\hline
\end{tabular}

shown in (1) and the weighting matrix to obtain a normalized weighted supermatrix $\bar{W}=A \times W=\left(\bar{W}_{i j}\right)_{n \times n}$, where the weighted matrix in the formula was obtained by comparing the importance of the relative criteria of element $C_{j}(j=1,2, \cdots, n)$ under the criterion of the first-level index $B_{i}$ :

$$
\begin{aligned}
& \begin{array}{llll}
C_{1} & C_{2} & \cdots & C_{n}
\end{array} \\
& W=\begin{array}{c|cccc}
C_{1} & W_{11} & W_{12} & \cdots & W_{1 n} \\
C_{2} & W_{21} & W_{22} & \cdots & W_{2 n} \\
\vdots & \vdots & \vdots & \vdots & \vdots \\
C_{n} & W_{n 1} & W_{n 2} & \cdots & W_{n n}
\end{array} \mid .
\end{aligned}
$$

Step 3. We performed stable processing on the supermatrix $W$ to generate the ANP limit matrix $W^{\infty}$ and then determined the index weights at all levels. We calculated the limit relative ordering vector of the supermatrix, as shown in (2). When $i$ tended to infinity and the limit convergence was unique, the column vector in the matrix was the stable weight of each assessment indicator:

$$
W^{\infty}=\lim _{i \rightarrow \infty}\left(\frac{1}{m}\right) \sum_{i=1}^{m} \bar{W}^{i} .
$$

Step 4. We constructed evaluation matrixes and performed fuzzy calculation. A fuzzy relation matrix $R=\left(r_{i j}\right) m \times n$, as shown in (3), was obtained by fuzzy linear transformation, where $r_{i j}=$ the number of the indicator number to select the level $v_{i} /$ the number of participating evaluation:

$$
R=\left(r_{i j}\right) m \times n\left|\begin{array}{cccc}
r_{11} & r_{12} & \cdots & r_{1 n} \\
r_{21} & r_{22} & \cdots & r_{2 n} \\
\vdots & \vdots & \vdots & \vdots \\
r_{m 1} & r_{m 2} & \cdots & r_{m n}
\end{array}\right| .
$$

Then, we established the overall evaluation vector. The overall evaluation vector $U_{i}$, as shown in (4), was established by the fuzzy comprehensive operation of the weight set and the fuzzy relation matrix:

$$
\begin{aligned}
U_{i} & =W_{i} \cdot R=\left(w_{i 1}, w_{i 2}, \ldots, w_{i m}\right) \cdot\left|\begin{array}{cccc}
r_{11} & r_{12} & \cdots & r_{1 n} \\
r_{21} & r_{22} & \cdots & r_{2 n} \\
\vdots & \vdots & \vdots & \vdots \\
r_{m 1} & r_{m 2} & \cdots & r_{m n}
\end{array}\right| \\
& =\left(u_{1}, u_{2}, \ldots, u_{n}\right) .
\end{aligned}
$$

Finally, the evaluation set that this paper selected was $V=\{$ good, relatively good, general, relatively poor, poor $\}$, and the quantified value set was $N=\{100,75,50,25,0\}$. The final performance evaluation score $F$, as shown in (5), was obtained by weighted average:

$$
F=100 \times u_{1}+75 \times u_{2}+50 \times u_{3}+25 \times u_{4}+0 \times u_{5} .
$$




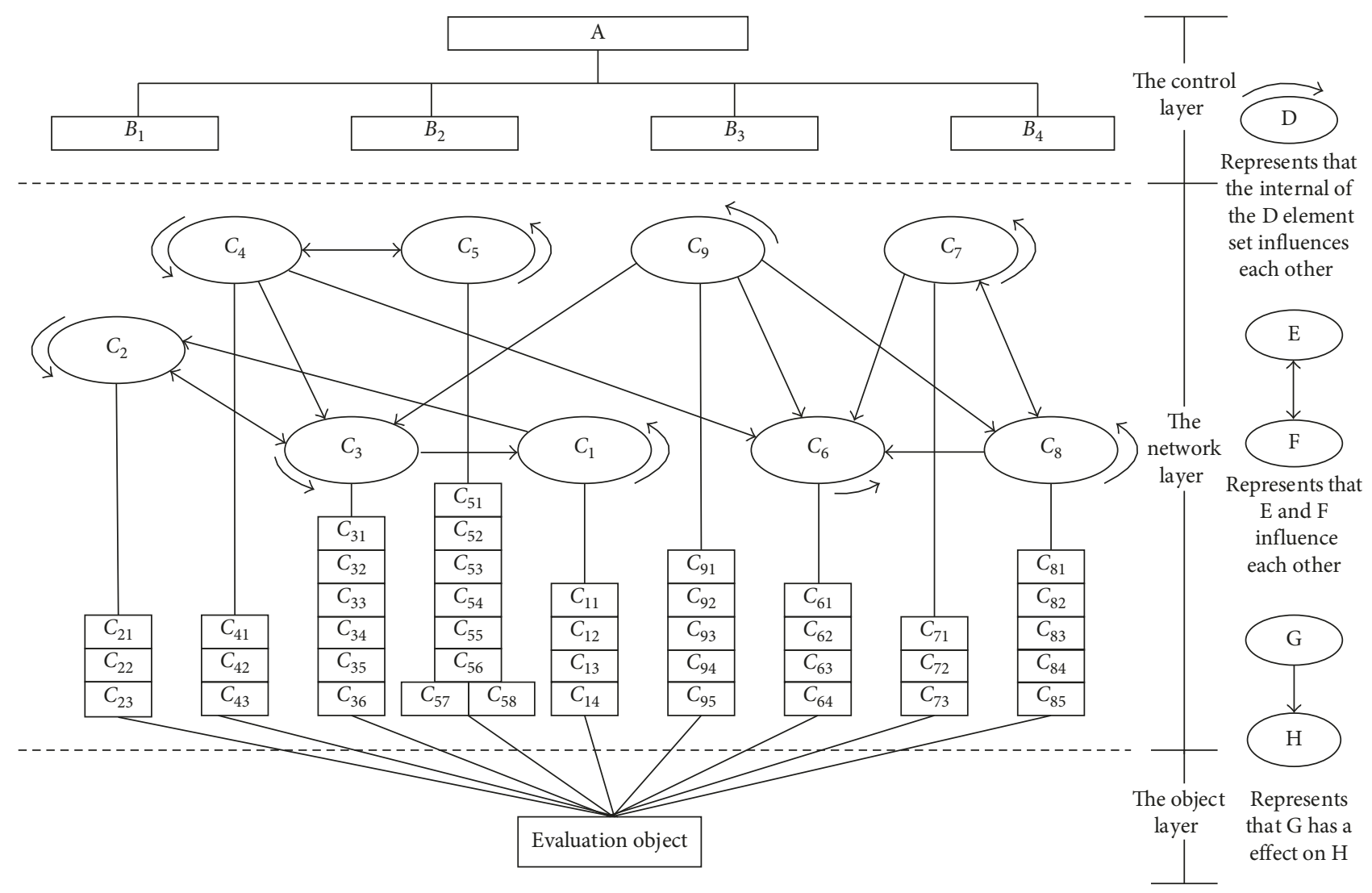

FIgURE 1: Network structure of the ANP for the food safety supervision in the sales link.

\section{Empirical Research}

Entrepreneurs reduced the sales cost to meet the consumer demand and to profit by maximizing their own interests and consumer utility because of moral considerations and other factors. As a result, food with secondary pollution, excessive microbial breeding, deterioration, and other safety hazards flowed into the market, impacting food safety at the source. The dairy industry will develop at a top speed in the next decade. The average growth rate of the annual output is $9.95 \%$, the popularity rate of urban dairy products is more than $95 \%$, and the average growth rate of the per capita consumption of dairy products in rural areas reaches $4.4 \%$ each year. The continuous consumption of substandard dairy products is adversely influencing the health of consumers. Therefore, dairy products were used as the evaluation object of the supervision status in sales.

4.1. Questionnaire Design. A questionnaire was developed based on the index system of assessing dairy products safety supervision in the sales link. The five-grade classification method was used to score each item in the questionnaire. In addition, in order to ensure the objectivity of scoring, each item was assigned a corresponding level of five scoring criteria. Specifically, "good" means 100 points, "relatively good" means 75 points, "general" means 50 points, "relatively poor" means 25 points, and "poor" means 0 points (the final score rating criteria of assessing the safety supervision of dairy products in the sales link are as follows: 100 points mean a full mark, 60 points and above indicate qualified, the score between $[0,30)$ is poor, the score between $[30,60)$ is relatively poor, the score between $[60,75)$ is general, the score between $[75,90)$ is relatively good, and the score between $[90,100]$ is well). Each evaluation index was simultaneously assigned a corresponding scoring criterion. We have conducted a presurvey to carry out the survey.

4.2. Data Sources. The survey on the situation of dairy products safety supervision in the sales link spanned from June 2016 to October 2016. The team collected relevant data before the end of September 2016. In this survey, each questionnaire represented one dairy merchant. Jiangsu Food and Drug Administration, as the official regulatory authority, is in charge of food and drug management and supervises the implementation of various systems and standards under the subordinate local governments according to the laws and regulations. Therefore, in the offline data collection work, the team cooperated with Jiangsu Food and Drug Administration. We entrusted it to investigate the situation of dairy product safety supervision in the sales link for different provinces in China and asked it to complete the data collection of offline situation of dairy product safety supervision in the sales link. A total of 322 completed questionnaires were obtained from 322 offline dairy businesses; 21 were invalid, and 301 were valid questionnaires; and the effective rate was $93.478 \%$. The team 
TABLE 2: Characteristics of e-commerce site sampled online.

\begin{tabular}{lcc}
\hline Website & Frequency & Proportion \\
\hline Taobao & 553 & 0.461 \\
Tmall & 238 & 0.198 \\
JD & 143 & 0.119 \\
Yhd & 88 & 0.073 \\
Suning & 68 & 0.057 \\
Feiniu & 29 & 0.024 \\
Sfbest & 12 & 0.010 \\
Amazon & 18 & 0.015 \\
Womai & 25 & 0.021 \\
Beibei & 8 & 0.007 \\
Ewj & 7 & 0.006 \\
JUMEI & 4 & 0.003 \\
GOU & 4 & 0.003 \\
Vip & 3 & 0.003 \\
\hline
\end{tabular}

TABLE 3: Characteristics of business type sampled online.

\begin{tabular}{lcc}
\hline Type & Frequency & Proportion \\
\hline Store operated by website & 187 & 0.156 \\
Official flagship store & 181 & 0.151 \\
Agent & 832 & 0.693 \\
\hline
\end{tabular}

members had completed the collection of online data by screening regulatory information that was publicly disclosed by e-commerce platforms. A total of 1,217 completed questionnaires were obtained from 1,217 online dairy businesses; 17 were invalid, and 1,200 were valid questionnaires; and the effective rate was $98.603 \%$. Therefore, 1,539 questionnaires were completed; 38 were invalid, and 1,501 were valid questionnaires; and the effective rate was $97.531 \%$. Finally, we had obtained 139,525 valid survey data.

4.3. Sample Characteristics. After being summarized, the data were classified by e-commerce platforms, brands of dairy products, and business types. The statistical data of 14 e-commerce platforms, 88 dairy brands, and 3 business types are shown in Tables 2-4, respectively. After being summarized, the data were classified by provinces. The statistical data of 7 provinces and 1 autonomous region are shown in Table 5.

4.4. Test of Reliability and Validity. The test of reliability and validity is a statistical method to test the rationality and effectiveness of the sample data, and it is a necessary step before the empirical analysis of the questionnaire. The SPSS 19.0 software was used to test the reliability and validity of the questionnaire in the paper, and the results were shown in Table 6. First, online, offline, and integral Cronbach's alpha (between 0.951 and 0.972) all exceeded the threshold of 0.7. Therefore, the questionnaire used in the survey indicated a high degree of reliability and good internal consistency, which indicated that the survey data were true and effective. Then, we used the KMO value and Bartlett's sphericity test to verify the validity of the questionnaire. From Table 6 , it could be seen that online, offline, and integral KMO all exceeded the threshold of 0.9, which indicated that a strong correlation existed in all indexes. The strong correlation was simultaneously reflected in significance, because each siginificance was all less than 0.05 . Therefore, the questionnaire also had a high degree of validity and was capable of meeting the research needs of this survey.

4.5. Evaluation and Analysis. On the basis of the above weight calculation method and the help of the Super decisions software, the weight of the indexes is obtained and is shown in Table 7.

Using the fuzzy-ANP comprehensive evaluation model, the score of the online and offline safety supervisions of dairy products in the sales link can be obtained, as shown in Table 8 . The score of the safety supervision of dairy products in the sales link for three e-commerce platforms can be determined, as indicted in Table 9. The score of the safety supervision of dairy products in the sales link for three types of online businesses can be determined, as shown in Table 10 . The score of the safety supervision of dairy products in the sales link for three offline provinces is presented in Table 11. In addition, it needs to be specifically stated that although dairy product safety supervision in the sales link has reached the "general" standard in the four classification methods, the actual safety regulatory situation is still not optimistic. As a result, dairy sales safety regulatory status incurred higher scores, and the actual safety regulatory situation is still not optimistic.

\section{Results}

Table 8 shows that in the two major sales channels of dairy products, the offline situation of dairy product safety supervision in the sales link gets the highest score, at a "relatively good" level. Compared with the offline situation, there is a gap in the scores of the online situation of dairy product safety supervision in the sales link, which is at a "general" level. In addition, from the score of integral situation of dairy product safety supervision in the sales link, we can see that China's integral situation of dairy product safety supervision in the sales link has reached a "general" standard, indicating that the government has implemented measures to promote the safety of dairy products in the sales link. However, the online food safety supervision of dairy products in the sales link still has deficiency to some extent, causing the integral situation of supervision not to achieve "relatively good." Therefore, the various food safety regulators should actively enhance their work ability to improve the safety supervision conditions.

Table 9 indicates that in the three online business platforms, Taobao's situation of dairy product safety supervision in the sales link gets the highest points and achieves a "relatively good" rating, followed by Tmall, and Jingdong, which are at a "general" rating. Affected by the development of network technology, the relevant information required for food safety supervision is not only getting fragmented and dispersed but also becomes more frequently transferred and shared among different entities. As a result, it is difficult for the government to obtain 
TABLE 4: Characteristics of dairy brands sampled on line.

\begin{tabular}{|c|c|c|}
\hline Brand & Frequency & Proportion \\
\hline $\mathrm{A}_{2}$ & 15 & 0.013 \\
\hline Organic Valley & 11 & 0.009 \\
\hline Cow \& Gate & 16 & 0.013 \\
\hline Friso & 20 & 0.017 \\
\hline Wiseng & 3 & 0.003 \\
\hline Similac & 10 & 0.008 \\
\hline Arla Foods & 18 & 0.015 \\
\hline Aptamil & 51 & 0.043 \\
\hline Ausnutria & 11 & 0.009 \\
\hline Bellamy's Organic & 20 & 0.017 \\
\hline Beingmate & 15 & 0.013 \\
\hline Be Strong & 15 & 0.013 \\
\hline Binggrae & 15 & 0.013 \\
\hline Hikid & 15 & 0.013 \\
\hline Weidendorf & 16 & 0.013 \\
\hline Devondale & 13 & 0.011 \\
\hline Suki & 11 & 0.009 \\
\hline Dumex & 17 & 0.014 \\
\hline Firmus Energy & 17 & 0.014 \\
\hline Fernbaby & 15 & 0.013 \\
\hline Flevomel & 4 & 0.003 \\
\hline Muh & 14 & 0.012 \\
\hline Treasure of Plateau & 16 & 0.013 \\
\hline GoldMax & 6 & 0.005 \\
\hline Bright Dairy & 17 & 0.014 \\
\hline BIOSTIME & 14 & 0.012 \\
\hline Globemilk & 10 & 0.008 \\
\hline Dutch Cow & 15 & 0.013 \\
\hline Heinz & 13 & 0.011 \\
\hline Huishan & 10 & 0.008 \\
\hline Murray Goulburn & 10 & 0.008 \\
\hline Wyeth & 16 & 0.013 \\
\hline Junlebao & 14 & 0.012 \\
\hline Cowala & 9 & 0.008 \\
\hline Karicare & 18 & 0.015 \\
\hline Laika & 14 & 0.012 \\
\hline Lactel & 9 & 0.008 \\
\hline Lebenswert & 2 & 0.002 \\
\hline Lotte & 11 & 0.009 \\
\hline Lowicz & 15 & 0.013 \\
\hline Lvlinb & 13 & 0.011 \\
\hline Royal group & 1 & 0.001 \\
\hline McJayden & 3 & 0.003 \\
\hline M.love & 10 & 0.008 \\
\hline Illuma & 19 & 0.016 \\
\hline Mead Johnson & 14 & 0.012 \\
\hline Mengniu Dairy & 20 & 0.017 \\
\hline Wissum & 15 & 0.013 \\
\hline Meiji & 13 & 0.011 \\
\hline Mum & 8 & 0.007 \\
\hline Shepherd & 1 & 0.001 \\
\hline Meadow fresh & 12 & 0.010 \\
\hline Nouriz & 15 & 0.013 \\
\hline Theland & 15 & 0.013 \\
\hline NUKA & 1 & 0.001 \\
\hline Nutrilon & 18 & 0.015 \\
\hline Aubecca & 13 & 0.011 \\
\hline Oldenburger & 18 & 0.015 \\
\hline Nestle & 42 & 0.035 \\
\hline Bright Beginnings & 7 & 0.006 \\
\hline Sunsides & 17 & 0.014 \\
\hline
\end{tabular}

TABle 4: Continued.

\begin{tabular}{lcc}
\hline Brand & Frequency & Proportion \\
\hline Living Planet & 14 & 0.012 \\
Shengmu & 21 & 0.018 \\
Synutra & 13 & 0.011 \\
Scient & 15 & 0.013 \\
Schardinger & 6 & 0.005 \\
Adimil & 13 & 0.011 \\
Happy Prince & 15 & 0.013 \\
Töpfer & 15 & 0.013 \\
Hero baby & 14 & 0.012 \\
Wondersun & 22 & 0.018 \\
Want Want & 18 & 0.015 \\
VIVA & 15 & 0.013 \\
VV & 10 & 0.008 \\
Weiquan & 15 & 0.013 \\
Xian & 2 & 0.002 \\
Babikins & 7 & 0.006 \\
HiPP & 15 & 0.013 \\
New Hope & 16 & 0.013 \\
Sanyuan & 25 & 0.021 \\
Yabais & 2 & 0.002 \\
YARiS & 2 & 0.002 \\
Abbott & 18 & 0.015 \\
YASHILI & 10 & 0.008 \\
Yili & 42 & 0.035 \\
YINSUTI & 9 & 0.008 \\
YOBETTER & 10 & 0.008 \\
\hline
\end{tabular}

supervision information and form effective supervision. It sets up strict platform responsibilities and transfers the supervisory responsibilities to e-commerce platforms with more information advantages. According to scores of the safety supervision of dairy products in the sales link for three e-commerce platforms, Taobao's food safety supervision of dairy products in the sales link is more standardized than Tmall and Jingdong. There is a certain degree of lack in Tmall and Jingdong's food safety supervision of dairy products in the sales link. Among them, Jingdong is doing the worst.

From Table 10, we can see that among the three business types of dairy products, the official flagship stores are in the highest safety supervision status, followed by the agents and the stores that are self-operated by website, which are all at the "general" level. It shows that the e-commerce platform has certain anomie and deficiency in food safety supervision of dairy products in the sales link for three business types. Among them, the food safety supervision of dairy products in the sales link for official flagship stores is more standardized than that of agents and the stores that are selfoperated by website, and the lack of supervision is the most serious in the stores that are self-operated by website. Combining with Table 8, we can analyze and see that China's offline situation of dairy product safety supervision in the sales link not reaching a good level is not dragged by a certain type of business, but all types of businesses need to strengthen the safety supervision in the sales link.

Table 11 shows that, in the offline three provinces, Zhejiang Province ranks first in the score of situation of dairy product safety supervision in the sales link, and Jiangsu ranks second with a small gap of 0.009 , both of which 
TABLE 5: Characteristics of province and region sampled offline.

\begin{tabular}{|c|c|c|c|c|}
\hline Province & Frequency & Proportion & City & Frequency \\
\hline \multirow{3}{*}{ Jiangxi } & \multirow{3}{*}{34} & \multirow{3}{*}{0.113} & Nanchang & 19 \\
\hline & & & Yichun & 6 \\
\hline & & & Jingdezhen & 9 \\
\hline \multirow[b]{2}{*}{ Gansu } & \multirow{2}{*}{11} & \multirow{2}{*}{0.037} & Jiayuguan & 7 \\
\hline & & & Dunhuang & 4 \\
\hline \multirow{2}{*}{ Anhui } & \multirow{2}{*}{13} & \multirow{2}{*}{0.043} & Suzhou & 6 \\
\hline & & & Hefei & 7 \\
\hline \multirow{2}{*}{ Guangdong } & \multirow{2}{*}{13} & \multirow{2}{*}{0.043} & Huizhou & 5 \\
\hline & & & Guangzhou & 8 \\
\hline \multirow{2}{*}{ Zhejiang } & \multirow{2}{*}{12} & \multirow{2}{*}{0.040} & Jiaxing & 3 \\
\hline & & & Ningbo & 9 \\
\hline \multirow[t]{6}{*}{ Xingjiang } & \multirow[t]{6}{*}{11} & \multirow[t]{6}{*}{0.037} & Hami & 11 \\
\hline & & & Changzhou & 5 \\
\hline & & & Huaian & 7 \\
\hline & & & Nanjing & 117 \\
\hline & & & Nantong & 10 \\
\hline & & & Suzhou & 5 \\
\hline \multirow{7}{*}{ Jiangsu } & \multirow{7}{*}{192} & \multirow{7}{*}{0.638} & Taizhou & 7 \\
\hline & & & Wuxi & 10 \\
\hline & & & Xuzhou & 5 \\
\hline & & & Yancheng & 6 \\
\hline & & & Yangzhou & 7 \\
\hline & & & Yixing & 8 \\
\hline & & & Zhenjiang & 5 \\
\hline Qinghai & 15 & 0.050 & Xining & 15 \\
\hline
\end{tabular}

reached a "relatively good" level. Qinghai Province ranks third in the score of situation of dairy product safety supervision in the sales link, but there is a big gap with the former two, which only reaches the "general" level. Combined with Table 8 and analyzing the score of offline situation of dairy product safety supervision in the sales link, we can see that although China's integral situation of dairy product safety supervision in the sales link reaches a relatively good level, there are polarization phenomena between different provinces. The situation of dairy product safety supervision in the sales link for some provinces is still not optimistic, and there is much room for improvement in food safety supervision of dairy products in the sales link.

\section{Discussion and Recommendations}

(1) This study finds that the integral situation of dairy product safety supervision in the sales link is generally average. Compared with the offline situation, the lack of online dairy product safety supervision in the sales link is more serious. With the accelerating pace of life, the online marketing mode of dairy products is being favored by more and more consumers with its unique service advantages such as online self-selection and logistics to home. Strengthening online supervision of dairy product safety in the sales link can effectively protect the rights and interests of the consumers. However, the result of the survey shows that the online situation of dairy product safety supervision in the sales link is not better than offline, and there is a big gap between each other. In addition, the in-depth analysis of the online situation of dairy product safety supervision in the sales link shows that of the all 41 evaluation indicators, only 33 achieve a "general" standard. Two indicators, namely, the frequency of regular physical examinations of operators and the ability to handle food safety incidents for sales are even at the failing level. This result indicates that government regulations are not implemented and below standard. The implementation of Article 44 "Food producers and traders shall establish and improve its own food safety management system, provide training of food safety to staffs, strengthen inspection of the foods, and conduct the food production and trading according to law" and Article 63 "Should food traders finding the occurrence of situation in the aforementioned paragraph, they should stop operation, information relevant producers/consumers, and record the measures taken. Should the food producer deem it necessary to recall the foods, the food shall be recalled immediately. Should the occurrence of situation in the aforementioned paragraph is ascribed to food traders, the foods shall be recalled immediately." of the "Food Safety Law" is insufficient, and the standards in the implementation of Article 53 "Food traders shall establish a purchase inspection and recording system. They shall truly record information such as name, specification, quantity, production date or batch number, shelf life, purchase date, as well as name, address and contact information of the supplier. The records and documents shall be kept in compliance with provisions in Article 50.2 of the Law" and 54 "Food producers and traders shall store, transport food in accordance with food safety assurance requirements, and regularly check the food in storage and remove the spoiled or outdated food in a timely" are substandard.

(2) From the rank of situation of dairy product safety supervision in the sales link for different e-commerce platforms, the investment in food safety supervision of dairy products in the sales link is insufficient for e-commerce platforms. At present, the usual practice of online food safety supervision in China is that the government transfers the regulatory cost to the platform and sets the strict platform responsibility to enable the platform to carry out deep management for food enterprises [2]. However, the score of situation of dairy product safety supervision in the sales link for three e-commerce platforms reflects that there is a lack of vacancy in the relevant supervision work, which has caused a certain risk of dairy products safety. The detailed analysis shows that although three sales qualification indicators of Tmall obtain a "relatively good" rating, 34 evaluation indicators only reach "general" standards. This phenomenon reveals that Tmall platform only focuses on qualification approval and pays minimal attention to follow-up supervision. JD obtains ratings of two 
TABLE 6: Test of reliability and validity.

\begin{tabular}{|c|c|c|c|c|c|}
\hline \multirow{2}{*}{ Subject of investigation } & \multirow{2}{*}{ Cronbach's alpha ${ }^{1}$} & \multirow{2}{*}{$\mathrm{KMO}^{2}$} & \multicolumn{3}{|c|}{ Bartlett's test of sphericity ${ }^{3}$} \\
\hline & & & Approximately chi-square & df & Significance \\
\hline Offline dairy business & 0.957 & 0.951 & 92336.27 & 1275 & 0.000 \\
\hline Online dairy business & 0.978 & 0.965 & 23171.39 & 1275 & 0.000 \\
\hline Whole dairy business & 0.975 & 0.972 & 111604.5 & 1275 & 0.000 \\
\hline
\end{tabular}

${ }^{1}$ Cronbach's alpha is the most commonly used method of reliability measurement, and its value is usually between 0 and 1 . If the alpha coefficient is not more than 0.6 , it is generally considered that the internal consistent reliability is insufficient; the expression scale is quite reliable when it reaches $0.7-0.8$, and the reliability of the scale is very good when it reaches $0.8-0.9$ [79]. ${ }^{2}$ The KMO (Kaiser-Meyer-Olkin) is an important index for testing validity of questionnaires. It is used to compare simple correlation coefficient and partial correlation coefficient among variables. If $\mathrm{KMO}>0.9$, the correlation between variables is very strong; if $0.9>\mathrm{KMO}>0.8$, the correlation between variables is strong; if $0.8>\mathrm{KMO}>0.7$, the correlation among variables is general; if $0.7>\mathrm{KMO}>0.6$, the correlation between variables is weak; and if HMO is less than 0.6 , there is no correlation between variables [80]. ${ }^{3}$ Bartlett's test of sphericity is a test method to examine the correlation degree among variables. Its statistic is based on the determinant of the correlation coefficient matrix. If the value is larger and its corresponding companion probability is less than the significant level in the user's mind, then the zero hypothesis should be rejected, that is, the correlation between the original variables. On the contrary, it is not suitable for factor analysis [81].

"general" and one "relatively poor" in the three indicators of sales qualification. Besides these, 33 evaluation indicators obtain a "general" rating, which indicates that some loopholes exist in examination and supervision. In contrast, the Taobao platform strengthens inspection due to the fake storm and previous tainted milk scandal, which caused the state to strengthen the supervision of small- and medium-sized businesses. Thus, Taobao works normally in food safety supervision of dairy products in the sales link. A total of 13 evaluation indicators under the sales qualification achieve a "relatively good" standard. According to Article 35 of the "Food Safety Law," the state shall adopt a licensing system for food production and operation. Enterprises engaged in food production, food sales, and catering services are mandated to obtain a sanitary license according to law. Article 62 states that a third-party e-commerce site provider of online food trade should register the name of net food operators and clarify the safety management responsibility of operators. If a food business obtains relative licenses according to law, an e-commerce site should also review their licenses.

(3) From the rank of situation of dairy product safety supervision in the sales link for different business types, online business types do not directly determine the situation of dairy product safety supervision in the sales link. Due to the existence of business reputation, the e-commerce platform will also increase regulatory input on the stores selfoperated by website and official flagship stores that represent the image of the platform to give consumers a safe and reliable impression of products sold in their platform [82]. However, the score of situation of dairy product safety supervision in the sales link for three business types does not support this deduction. The detailed analysis shows that the situation of supervision in operating environment, quality of sales personnel, and warehouse management is not optimistic for all three business types. In addition, the official flagship stores achieve
TABle 7: Index weight.

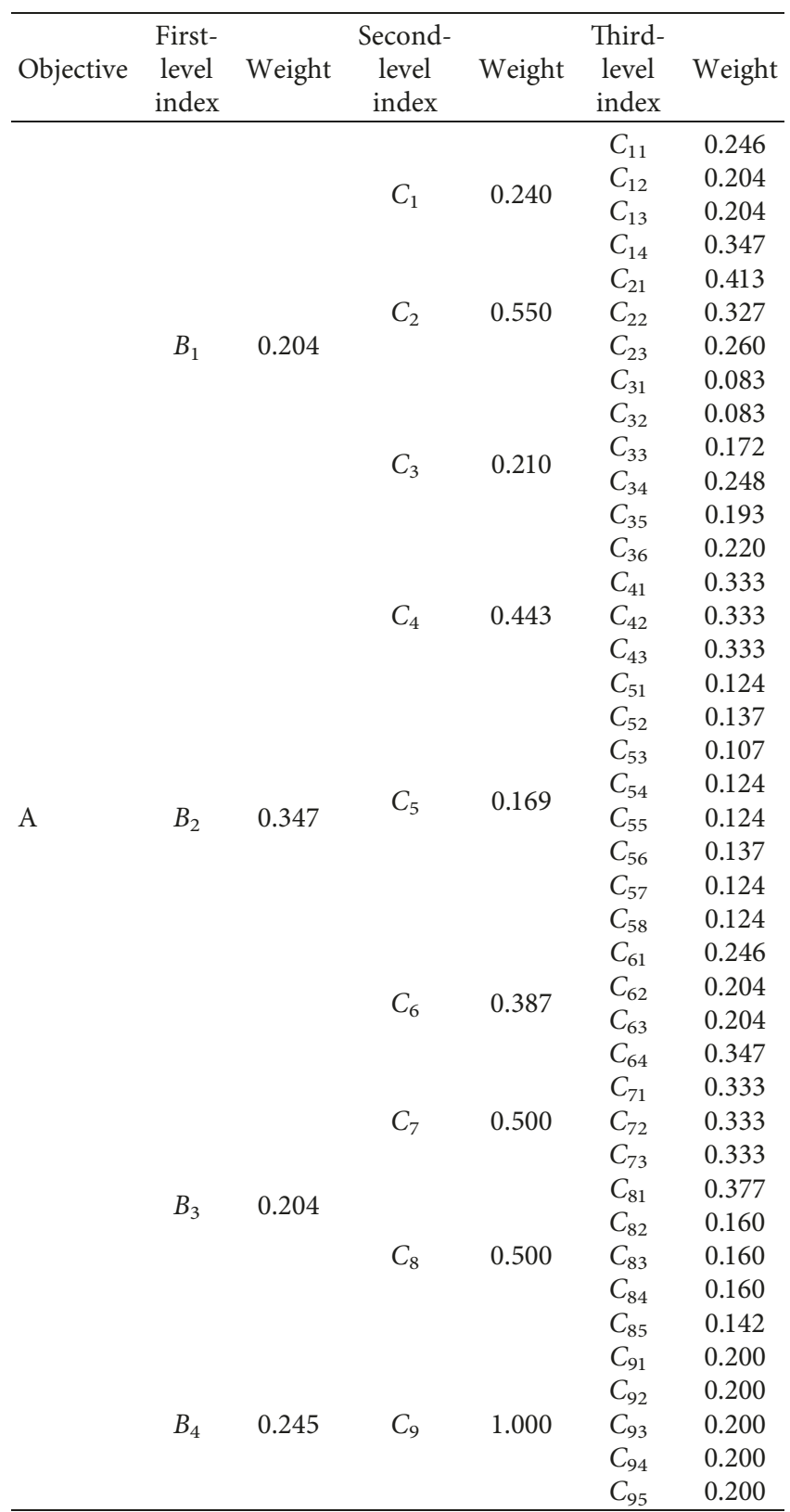


TABLE 8: Scores of the online, offline, and integral safety supervision of dairy products in the sales link.

\begin{tabular}{|c|c|c|c|c|c|c|c|}
\hline Evaluation goal & Good & Relatively good & General & Relatively poor & Poor & Score & Grade \\
\hline $\begin{array}{l}\text { Online situation of dairy product } \\
\text { safety supervision in the sales link }\end{array}$ & 0.27 & 0.411 & 0.275 & 0.029 & 0.015 & 72.276 & General \\
\hline $\begin{array}{l}\text { Offline situation of dairy product } \\
\text { safety supervision in the sales link }\end{array}$ & 0.439 & 0.333 & 0.193 & 0.03 & 0.005 & 79.29 & Relatively good \\
\hline $\begin{array}{l}\text { Integral situation of dairy product } \\
\text { safety supervision in the sales link }\end{array}$ & 0.304 & 0.396 & 0.258 & 0.029 & 0.013 & 73.682 & General \\
\hline
\end{tabular}

TABLE 9: Scores of the safety supervision of dairy products in the sales link for three e-commerce platforms ${ }^{1}$.

\begin{tabular}{|c|c|c|c|c|c|c|c|}
\hline Evaluation goal & Good & Relatively good & General & Relatively poor & Poor & Score & Grade \\
\hline $\begin{array}{l}\text { Taobao's situation of dairy product } \\
\text { safety supervision in the sales link }\end{array}$ & 0.374 & 0.347 & 0.233 & 0.037 & 0.009 & 75.992 & Relatively good \\
\hline $\begin{array}{l}\text { Tmall's situation of dairy product } \\
\text { safety supervision in the sales link }\end{array}$ & 0.237 & 0.444 & 0.297 & 0.019 & 0.004 & 72.258 & General \\
\hline $\begin{array}{l}\text { JD's situation of dairy product safety } \\
\text { supervision in the sales link }\end{array}$ & 0.135 & 0.554 & 0.232 & 0.02 & 0.059 & 67.134 & General \\
\hline
\end{tabular}

${ }^{1}$ The 2015 dairy products big business report shows that the three e-commerce sites occupy dairy sales share of $80.6 \%$ in online channels; thus, these e-commerce sites can be chosen to analyze the online safety regulatory condition of dairy sales.

TABLE 10: Scores of the safety supervision of dairy products in the sales link for three types of online businesses ${ }^{1}$.

\begin{tabular}{|c|c|c|c|c|c|c|c|}
\hline Evaluation goal & Good & Relatively good & General & Relatively poor & Poor & Score & Grade \\
\hline $\begin{array}{l}\text { Agent situation of dairy product safety supervision } \\
\text { in the sales link }\end{array}$ & 0.281 & 0.389 & 0.281 & 0.032 & 0.017 & 72.12 & General \\
\hline $\begin{array}{l}\text { Stores that are self-operated by website situation } \\
\text { of dairy product safety supervision in the sales link }\end{array}$ & 0.206 & 0.464 & 0.3 & 0.017 & 0.013 & 70.829 & General \\
\hline $\begin{array}{l}\text { Official flagship stores' situation of dairy product } \\
\text { safety supervision in the sales link }\end{array}$ & 0.285 & 0.459 & 0.219 & 0.026 & 0.012 & 74.482 & General \\
\hline
\end{tabular}

${ }^{1}$ The official flagship store for dairy products is an online store opened by the dairy product owners after they have been certified by e-commerce platforms such as Taobao and Jingdong. Dairy products stores that are self-operated by website refer to an online store where the website sells products directly on its own platform (not a third-party seller) after authorization by the dairy brand owner.

TABLE 11: Scores of the safety supervision of dairy products in the sales link for three offline provinces ${ }^{1}$.

\begin{tabular}{|c|c|c|c|c|c|c|c|}
\hline Evaluation goal & Good & Relatively good & General & Relatively poor & Poor & Score & Grade \\
\hline $\begin{array}{l}\text { Jiangsu's situation of dairy product safety } \\
\text { supervision in the sales link }\end{array}$ & 0.423 & 0.335 & 0.207 & 0.031 & 0.005 & 78.467 & Relatively good \\
\hline $\begin{array}{l}\text { Zhejiang's situation of dairy product safety } \\
\text { supervision in the sales link }\end{array}$ & 0.449 & 0.33 & 0.156 & 0.039 & 0.026 & 78.476 & Relatively good \\
\hline $\begin{array}{l}\text { Qinghai's situation of dairy product safety } \\
\text { supervision in the sales link }\end{array}$ & 0.303 & 0.251 & 0.375 & 0.072 & 0 & 69.609 & General \\
\hline
\end{tabular}

${ }^{1}$ According to the total GDP data released by the provinces in 2015, choosing Jiangsu Province, Zhejiang Province, and Qinghai Province as representatives can compare the differences of the situation of dairy product safety supervision in sales link between economically developed provinces and provinces with relatively backward economic development.

a "relatively good" evaluation in seven aspects including the temperature range that facilities can be set to, the health certificate of operators, the frequency of regular trainings on food safety knowledge and technology, the moral level of operators, the legality of the content of the food marketing ad, the establishment of food delisting system for sales unit, and the ability to handle food safety incidents for sales. Agents achieve a "relatively good" evaluation in the following five aspects: sales qualification, the completeness and authenticity of food specific information, and the completeness and authenticity of
Chinese information for food imports. However, stores operated by website only achieve a "relatively good" rating in sales qualification, hygienic qualification rate of equipment, and other two indexes. The situation of dairy product safety supervision in the sales link is uneven for three business types and does not show a direct connection with the business type.

(4) From the rank of situation of dairy product safety supervision in the sales link for different provinces, the economic development level of offline provinces will have an impact on the situation of dairy product safety supervision in the sales link. The backwardness 
of the economic development can limit investment in food safety supervision in the sales link, resulting in a poor safety supervision in the sales link [83]. The score of situation of dairy product safety supervision in the sales link for Jiangsu Province, Zhejiang Province, and Qinghai Province further confirmed the viewpoint. The detailed analysis shows that due to the government's focus on urban construction and economic development, Qinghai Province's investment in food safety supervision to improve people's livelihood is lacking. As a result, it caused the situation of supervision for Qinghai Province to obtain a good rating in three indicators of the qualifications of sales units that are strictly supervised by the state, and the other 38 safety supervision indicators for dairy products in the sales link have only reached the general level. In contrast, both Jiangsu Province and Zhejiang Province, which are representatives of the eastern coastal developed regions of China, have more than 15 evaluation indicators that have achieved "relatively good," and even Zhejiang Province has two other indicators rated as "good."

\subsection{Recommendations}

(1) The supervision department should unite consumers, the media, and third-party authorities in supervising the food safety of dairy products in the sales link to achieve social cogovernance. The safety accidents of the dairy products in recent years demonstrate a certain regulatory loophole in the single government regulatory model. These accidents also indicate the regulation principle in which the "divided monitoring model of food safety is the most important, and the species supervision is less important" includes including a number of mistakes. Therefore, the government should encourage all stakeholders to actively participate in supervising the safety of dairy product sales in the future to form a regulatory network covering the entire society.

(2) e-Commerce platforms should improve the market access threshold, strengthen the qualification examination, and supervision of the dairy industry from the source to create good online dairy sales environment. The online situation of dairy product safety supervision in the sales link is not optimistic. The main reason is that cyberspace has virtual and dynamic characteristics, so supervision and management become ineffective for government. The online safety supervision of the dairy product in the sales link is more depended on the e-commerce platforms. Meanwhile, some e-commerce platforms only establish a "relatively low" market access threshold and lack long-term regulatory mechanisms. As a result, unqualified businesses can enter the sale market. Thus, e-commerce platforms should conduct dairy product qualification audit and adopt other regulatory mechanisms to improve the online situation of dairy product safety supervision in the sales link.
(3) The state should quickly develop a unified evaluation system for the food safety of dairy products in the sales link to narrow the gap between different areas and to improve social trust in dairy safety. For a long time, there are few supporting policies to standardize the downstream of the dairy industry chain, especially the circulation channels and sales links, and the formulation of relevant supporting policies is lack of unity, professionalism, and authority [14]. The phenomenon leads to the fact that different areas have various regulatory contents and regulatory emphases. The regulatory level of China's situation of dairy product safety supervision in the sales link is uneven, and a certain degree of hidden danger exists in the overall dairy products safety. Thus, the state should speed up the process of making uniform policies to ensure the safety of dairy products in the sales link, which regulates the supervision work of the main body of government supervision and reduces the hidden danger in sales link.

\section{Conclusion}

The empirical results are as follows:

(1) The overall situation of dairy product safety supervision in the sales link is encumbered by the fact that the online situation of dairy product safety supervision in the sales link is general. It does not achieve a relatively good level.

(2) The investment in food safety supervision of dairy products in the sales link is insufficient for the online e-commerce platforms. Especially, the processes of reviewing and approving relevant business sales qualification must be improved.

(3) Online business types do not directly determine the situation of dairy product safety supervision in the sales link, but the operating environment, sales staff quality, and warehousing management are common regulatory weaknesses.

(4) For offline provinces, the level of economic development can affect the situation of dairy product safety supervision in the sales link. Aside from emphasizing sales qualifications, economically backward provinces should improve the supervision of operating environment, sales equipment, sanitary status of workers, and other aspects.

\section{Data Availability}

The data used to support the findings of this study are available from the corresponding author upon request.

\section{Disclosure}

Tingqiang Chen, Shuaibin Wang, and Lei Pei are the co-first authors. 


\section{Conflicts of Interest}

The authors declare that they have no conflicts of interest.

\section{Authors' Contributions}

Tingqiang Chen, Shuaibin Wang, and Lei Pei contributed equally to this work.

\section{Acknowledgments}

This work was supported by the National Natural Science Foundation of China (no. 71501094), Natural Science Foundation of Jiangsu Province of China (no. BK20150961), Key Project of Philosophy and Social Science Research in Colleges and Universities in Jiangsu Province (no. 2017ZDIXM074), Innovation Team Project of Philosophy and Social Sciences in Colleges and Universities in Jiangsu Province (no. 2017ZSTD005), Jiangsu Higher Education Institutions sponsored by Qing Lan Project, and Nanjing Tech University Philosophy and Social Science Research Innovation Team Funding Projects (SKTD201503).

\section{References}

[1] A. P. J. Mol, "Governing China's food quality through transparency: a review," Food Control, vol. 43, pp. 49-56, 2014.

[2] C. Jia and D. Jukes, "The national food safety control system of China-a systematic review," Food Control, vol. 32, no. 1, pp. 236-245, 2013.

[3] E. I. Broughton and D. G. Walker, "Policies and practices for aquaculture food safety in China," Food Policy, vol. 35, no. 5, pp. 471-478, 2010.

[4] E. Jones, A. Poghosyan, F. Gonzalezdiaz et al., "Traceability and assurance protocols in the global food system," International Food and Agribusiness Management Review, vol. 7, no. 3, pp. 118-126, 2004.

[5] L. Fulponi, "Private voluntary standards in the food system: the perspective of major food retailers in OECD countries," Food Policy, vol. 31, no. 1, pp. 1-13, 2006.

[6] L. L. Xu and L. H. Wu, "Food safety and consumer willingness to pay for certified traceable food in China," Journal of the Science of Food and Agriculture, vol. 90, no. 8, pp. 1368-1373, 2010.

[7] M. R. Darby and E. Karni, "Free competition and the optimal amount of fraud," Journal of Law and Economics, vol. 16, no. 1, pp. 67-88, 1973.

[8] S. A. Starbird, "Moral hazard, inspection policy, and food safety," American Journal of Agricultural Economics, vol. 87, no. 1, pp. 15-27, 2005.

[9] J. Wang, T. Chen, and J. Wang, "Research on cooperation strategy of enterprises' quality and safety in food supply Chain," Discrete Dynamics in Nature and Society, vol. 2015, Article ID 301245, 15 pages, 2015.

[10] L. J. Frewer, C. Howard, D. Hedderley, and R. Shepherd, "Methodological approaches to assessing risk perceptions associated with food-related hazards," Risk Analysis, vol. 18, no. 1, pp. 95-102, 1998.

[11] S. Rosati and A. Saba, "The perception of risks associated with food-related hazards and the perceived reliability of sources of information," International Journal of Food Science and Technology, vol. 39, no. 5, pp. 491-500, 2010.
[12] R. Liu, Z. Pieniak, and W. Verbeke, "Food-related hazards in China: consumers' perceptions of risk and trust in information sources," Food Control, vol. 46, no. 46, pp. 291-298, 2014.

[13] C. C. Hinrichs, "The practice and politics of food system localization," Journal of Rural Studies, vol. 19, no. 1, pp. 33-45, 2003.

[14] X. Pei, A. Tandon, A. Alldrick, L. Giorgi, W. Huang, and R. Yang, "The China melamine milk scandal and its implications for food safety regulation," Food Policy, vol. 36, no. 3, pp. 412-420, 2011.

[15] T. Chen, L. Wang, J. Wang, and Q. Yang, "A network diffusion model of food safety scare behavior considering information transparency," Complexity, vol. 2017, article 5724925, 16 pages, 2017.

[16] E. K. Silbergeld, J. Graham, and B. L. Price, "Industrial food animal production: food safety, socioeconomic, and environmental health concerns," Epidemiology, vol. 19, no. 6, pp. S15-S16, 2008.

[17] M. P. Doyle, "Food safety issues arising at food production in a global market," Journal of Agribusiness, vol. 18, no. 1, pp. 129-133, 2009.

[18] Y. Hu and H. Cheng, "Health risk from veterinary antimicrobial use in China's food animal production and its reduction," Environmental Pollution, vol. 219, pp. 993-997, 2016.

[19] V. Boxstael, I. Habib, L. Jacxsens et al., "Food safety issues in fresh produce: bacterial pathogens, viruses and; pesticide residues indicated as major concerns by stakeholders in the fresh produce chain," Food Control, vol. 32, no. 1, pp. 190-197, 2013.

[20] J. Zhou, J. H. Helen, and J. Liang, "Implementation of food safety and quality standards: a case study of vegetable processing industry in Zhejiang," China Social Science Journal, vol. 48, no. 3, pp. 543-552, 2011.

[21] R. D. Q. Rodrigues, M. R. Loiko, C. M. D. D. Paula et al., "Microbiological contamination linked to implementation of good agricultural practices in the production of organic lettuce in Southern Brazil," Food Control, vol. 42, no. 2, pp. 152-164, 2014.

[22] Z. Chan and W. F. Lai, "Revisiting the melamine contamination event in China: implications for ethics in food technology," Trends in Food Science and Technology, vol. 20, no. 8, pp. 366-373, 2009.

[23] X. Wu, Y. Lu, H. Xu et al., "Challenges to improve the safety of dairy products in China," Trends in Food Science and Technology, vol. 76, pp. 6-14, 2018.

[24] A. Liu and R. Niyongira, "Chinese consumers food purchasing behaviors and awareness of food safety," Food Control, vol. 79, no. 9, pp. 185-191, 2017.

[25] Y. Cao, X. Liu, C. Guan, and B. Mao, "Implementation and current status of food traceability system in Jiangsu China," Procedia Computer Science, vol. 122, pp. 617-621, 2017.

[26] M. M. Aung and Y. S. Chang, "Temperature management for the quality assurance of a perishable food supply chain," Food Control, vol. 40, no. 1, pp. 198-207, 2014.

[27] S. J. Walker, P. Archer, and J. G. Banks, "Growth of Listeria monocytogenes at refrigeration temperatures," Journal of Applied Microbiology, vol. 68, no. 2, pp. 157-162, 2010.

[28] J. Lundén, V. Vanhanen, K. Kotilainen, and K. Hemminki, "Retail food stores' internet-based own-check databank records and health officers' on-site inspection results for cleanliness and food holding temperatures reveal inconsistencies," Food Control, vol. 35, no. 1, pp. 79-84, 2014. 
[29] M. Bader, E. Blonder, J. Henriksen, and W. Strong, "A study of food service establishment sanitation inspection frequency," American Journal of Public Health, vol. 68, no. 4, pp. 408-410, 1978.

[30] K. Aarnisalo, K. Tallavaara, G. Wirtanen, R. Maijala, and L. Raaska, "The hygienic working practices of maintenance personnel and equipment hygiene in the Finnish food industry," Food Control, vol. 17, no. 12, pp. 1001-1011, 2006.

[31] J. M. Lundén, T. J. Autio, A. M. Sjöberg, and J. H. Korkeala, "Persistent and nonpersistent Listeria monocytogenes contamination in meat and poultry processing plants," Journal of Food Protection, vol. 66, no. 11, pp. 2062-2069, 2003.

[32] V. I. Triantafyllou, K. Akridademertzi, and P. G. Demertzis, "A study on the migration of organic pollutants from recycled paperboard packaging materials to solid food matrices," Food Chemistry, vol. 101, no. 4, pp. 1759-1768, 2007.

[33] M. D. F. Poças and T. Hogg, "Exposure assessment of chemicals from packaging materials in foods: a review," Trends in Food Science and Technology, vol. 18, no. 4, pp. 219-230, 2007.

[34] K. Grob, M. Biedermann, E. Scherbaum, M. Roth, and K. Riege, "Food contamination with organic materials in perspective: packaging materials as the largest and least controlled source? A view focusing on the European situation," Critical Reviews in Food Science and Nutrition, vol. 46, no. 7, pp. 529-535, 2006.

[35] R. Franz, "Programme on the recyclability of food-packaging materials with respect to food safety considerations: polyethylene terephthalate (PET), paper and board, and plastics covered by functional barriers," Food Additives and Contaminants, vol. 19, no. 1, pp. 93-110, 2002.

[36] K. Cooksey, "Effectiveness of antimicrobial food packaging materials," Food Additives and Contaminants, vol. 22, no. 10, pp. 980-987, 2005.

[37] P. Alessandra, L. Carmen, M. Marzia et al., "Food safety concerns deriving from the use of silver based food packaging materials," Frontiers in Microbiology, vol. 6, no. 1109, pp. 1-7, 2015.

[38] E. M. Buys, G. L. Nortjé, P. J. Jooste, and A. Von Holy, "Bacterial populations associated with bulk packaged beef supplemented with dietary vitamin E," International Journal of Food Microbiology, vol. 56, no. 2, pp. 239-244, 2000.

[39] N. Route, "HACCP and SMEs: a case study," in Making the Most of HACCP, pp. 32-42, Elsevier, Amsterdam, Netherlands, 2001.

[40] D. Djenane, A. Sánchez-Escalante, J. A. Beltrán, and P. Roncalés, "Extension of the retail display life of fresh beef packaged in modified atmosphere by varying lighting conditions," Journal of Food Science, vol. 66, no. 1, pp. 181-186, 2010.

[41] R. Akkerman, D. van der Meer, and D. Pieter van Donk, "Make to stock and mix to order: choosing intermediate products in the food-processing industry," International Journal of Production Research, vol. 48, no. 12, pp. 3475-3492, 2010.

[42] G. Tebbutt, V. Bell, and J. Aislabie, "Verification of cleaning efficiency and its possible role in programmed hygiene inspections of food businesses undertaken by local authority officers," Journal of Applied Microbiology, vol. 102, no. 4, pp. 1010-1017, 2007.

[43] C.-C. Liang, "Smart inventory management system of foodprocessing-and-distribution industry," Procedia Computer Science, vol. 17, pp. 373-378, 2013.

[44] M. B. Lubran, R. Pouillot, S. Bohm, M. E. Calvey, J. Meng, and S. Dennis, "Observational study of food safety practices in retail deli departments," Journal of Food Protection, vol. 73, no. 10, pp. 1849-1857, 2010.

[45] K. J. Awosan, M. O. Oche, E. U. Yunusa et al., "Knowledge, risk perception and practices regarding the hazards of unsanitary solid waste disposal among small-scale business operators in Sokoto, Nigeria," International Journal of Tropical Disease and Health, vol. 26, no. 2, pp. 1-10, 2017.

[46] N. M. Nawi and N. I. M. Nasir, "Consumers" attitude toward the food safety certificate (FSC) in Malaysia," Journal of Food Products Marketing, vol. 20, no. 1, pp. 140-150, 2014.

[47] M. Bruhn, "License to sell: the effect of business registration reform on entrepreneurial activity in Mexico," Policy Research Working Paper, vol. 93, no. 1, pp. 382-386, 2011.

[48] I. Mclaughlin and K. Kramer, "Food retailer licensing: an innovative approach to increasing access to healthful foods," Preventing Chronic Disease, vol. 9, no. 6, pp. E170-E173, 2012.

[49] A. Friedberg, R. Schwartz, and S. Amrani, "Oversight ethics: the case of business licensing," Journal of Business Ethics, vol. 53, no. 4, pp. 371-381, 2004.

[50] L. E. Lee, O. Niode, A. H. Simonne, and M. C. Bruhn, "Consumer perceptions on food safety in Asian and Mexican restaurants," Food Control, vol. 26, no. 2, pp. 531-538, 2010.

[51] E. C. D. Todd, B. S. Michaels, J. D. Greig, D. Smith, J. Holah, and A. C. Bartleson, "Outbreaks where food workers have been implicated in the spread of foodborne disease, part 7 . Barriers to reduce contamination of food by workers," Journal of Food Protection, vol. 73, no. 8, pp. 1552-1565, 2010.

[52] M. P. Azanza, C. F. Gatchalian, and M. P. Ortega, "Food safety knowledge and practices of streetfood vendors in a Philippines university campus," International Journal of Food Sciences and Nutrition, vol. 51, no. 4, pp. 235-246, 2000.

[53] E. C. D. Todd, "Food safety assurance systems: personal hygiene and employee health," Encyclopedia of Food Safety, vol. 4, pp. 201-210, 2014.

[54] N. Li and W. H. Murphy, "A three-country study of unethical sales behaviors," Journal of Business Ethics, vol. 111, no. 2, pp. 219-235, 2012.

[55] M. B. Egan, M. M. Raats, S. M. Grubb et al., "A review of food safety and food hygiene training studies in the commercial sector," Food Control, vol. 18, no. 10, pp. 1180-1190, 2007.

[56] J. A. Caswell and D. I. Padberg, "Toward a more comprehensive theory of food labels," American Journal of Agricultural Economics, vol. 74, no. 2, pp. 460-468, 1992.

[57] L. Zach, M. E. Doyle, V. Bier, and C. Czuprynski, "Systems and governance in food import safety: A U.S. perspective," Food Control, vol. 27, no. 1, pp. 153-162, 2012.

[58] M. O. Lwin, "Comparative practices of food label claims from US, EU and selected southeast Asian countries," Journal of Consumer Marketing, vol. 32, no. 7, pp. 530-541, 2015.

[59] B. S. Anami and D. G. Savakar, "Effect of foreign bodies on recognition and classification of bulk food grains image samples," Journal of Applied Computer Science and Mathematics, vol. 3, no. 6, pp. 77-83, 2009.

[60] F. Boncinelli, F. Gerini, G. Pagnotta, and F. Alfnes, "Warning labels on junk food: experimental evidence," International Journal of Consumer Studies, vol. 41, no. 1, pp. 46-53, 2017.

[61] H. Sumino, "Measures to "defects of warning and label" in the product liability of food industry," Current Opinion in Clinical Nutrition and Metabolic Care, vol. 2, no. 6, pp. 481-484, 1999.

[62] J. A. Alfaro and L. A. Rábade, "Traceability as a strategic tool to improve inventory management: a case study in the food industry," International Journal of Production Economics, vol. 118, no. 1, pp. 104-110, 2009. 
[63] M. Bertolini, E. Bottani, A. Rizzi et al., "Shrinkage reduction in perishable food supply chain by means of an RFID-based FIFO management policy," International Journal of $R F$ Technologies Research and Applications, vol. 5, no. 3-4, pp. 123-136, 2013.

[64] Y. Y. Chen, J. K. Jan, M. L. Tsai et al., "On the security of RFID-based monitoring mechanism for retail inventory management," KSII Transactions on Internet and Information Systems, vol. 6, no. 2, pp. 515-528, 2012.

[65] J. Jang, "The study of efficient store operations through the development of local food inventory management system," Journal of Advanced Information Technology and Convergence, vol. 6, no. 2, pp. 19-31, 2016.

[66] M. M. Aung and Y. S. Chang, "Traceability in a food supply chain: safety and quality perspectives," Food Control, vol. 39, no. 1, pp. 172-184, 2014.

[67] J. Bai, T. I. Wahl, and J. J. McCluskey, "Consumer choice of retail food store formats in Qingdao, China," Journal of International Food and Agribusiness Marketing, vol. 20, no. 2, pp. 89-109, 2008.

[68] S. V. Boxstael, F. Devlieghere, D. Berkvens, A. Vermeulen, and M. Uyttendaele, "Understanding and attitude regarding the shelf life labels and dates on pre-packed food products by Belgian consumers," Food Control, vol. 37, no. 1, pp. 85-92, 2014.

[69] R. Garayoa, M. Córdoba, I. Garcíajalón, A. Sanchez-Villegas, and A. I. Vitas, "Relationship between consumer food safety knowledge and reported behavior among students from health sciences in one region of Spain," Journal of Food Protection, vol. 68, no. 12, pp. 2631-2636, 2005.

[70] G. M. Guiducci, F. D. Copeland, T. Dorsey, and S. Edelstein, "A review of the food establishment inspection reports in Boston, Massachusetts," Topics in Clinical Nutrition, vol. 26, no. 2, pp. 165-170, 2011.

[71] A. Leal, T. K. Ruth, J. N. Rumble, and A. H. Simonne, "Exploring Florida residents' food safety knowledge and behaviors: a generational comparison," Food Control, vol. 73, pp. 1195-1202, 2016.

[72] S. K. Keller and P. J. Schulz, "Distorted food pyramid in kids programmes: a content analysis of television advertising watched in Switzerland," European Journal of Public Health, vol. 21, no. 3, pp. 300-305, 2011.

[73] R. Lofstedt, "Risk communication and the FSA: the food colourings case," Journal of Risk Research, vol. 12, no. 5, pp. 537-557, 2009.

[74] W. Cheung, I. T. Shadi, Y. Xu, and R. Goodacre, "Quantitative analysis of the banned food dye Sudan-1 using surface enhanced Raman scattering with multivariate chemometrics," Journal of Physical Chemistry C, vol. 114, no. 16, pp. 72857290, 2010.

[75] K. Fujimura and M. Terada, Trading among Untrusted Partners via Voucher Trading System, Springer, New York, NY, USA, 2002.

[76] S. Charlebois, "Food recalls, systemic causal factors and managerial implications," British Food Journal, vol. 113, no. 5, pp. 625-636, 2011.

[77] T. L. Saaty, "Modeling unstructured decision problems-the theory of analytical hierarchies," Mathematics and Computers in Simulation, vol. 20, no. 3, pp. 147-158, 1978.

[78] A. Sala, T. M. Guerra, and R. Babuška, "Perspectives of fuzzy systems and control," Fuzzy Sets and Systems, vol. 156, no. 3, pp. 432-444, 2005.

[79] L. J. Cronbach, "Coefficient alpha and the internal structure of tests,” Psychometrika, vol. 16, no. 3, pp. 297-334, 1951.
[80] H. F. Kaiser and J. Rice, "Little Jiffy, Mark IV,” Educational and Psychological Measurement, vol. 34, no. 1, pp. 111-117, 1974.

[81] M. Norusis, SPSS 16.0 Guide to Data Analysis, Prentice Hall Press, Upper Saddle River, NJ, USA, 2008.

[82] R. Chen, Y. Zheng, W. Xu, M. Liu, and J. Wang, "Secondhand seller reputation in online markets: a text analytics framework," Decision Support Systems, vol. 108, pp. 96-106, 2018.

[83] Y. Y. Lin, H. Zeng, G. C. Li, and H.-G. Ni, "Economic development is ultimate determinant of food safety: a case study of China," Environmental Pollution, vol. 158, no. 5, pp. 1185-1188, 2010. 


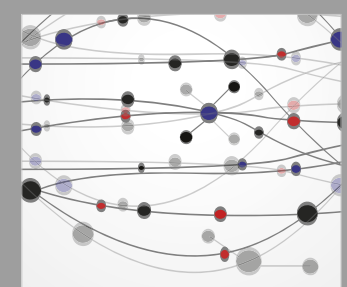

The Scientific World Journal
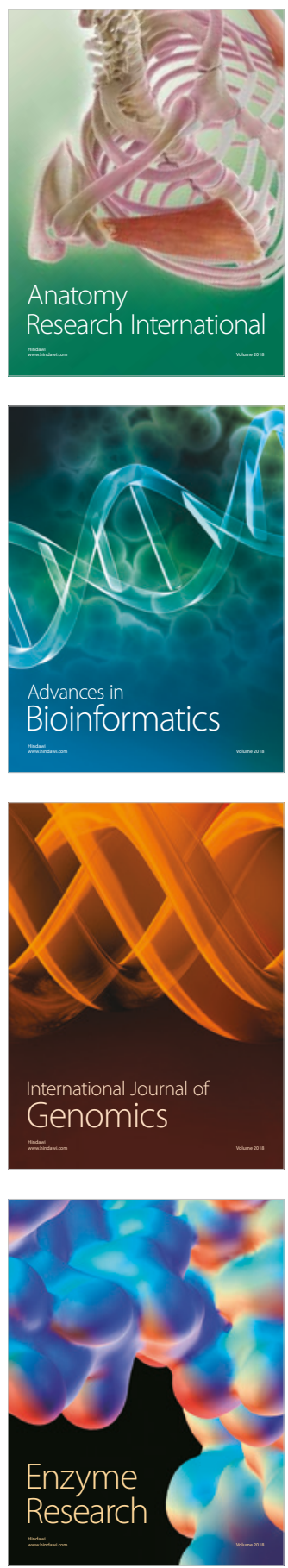
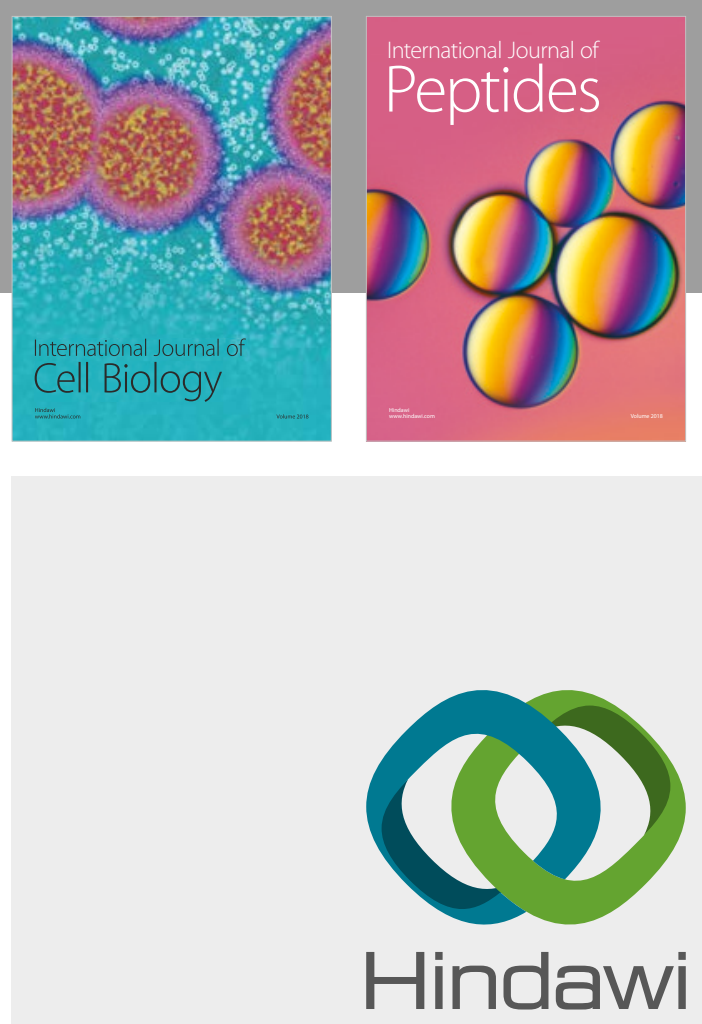

Submit your manuscripts at

www.hindawi.com
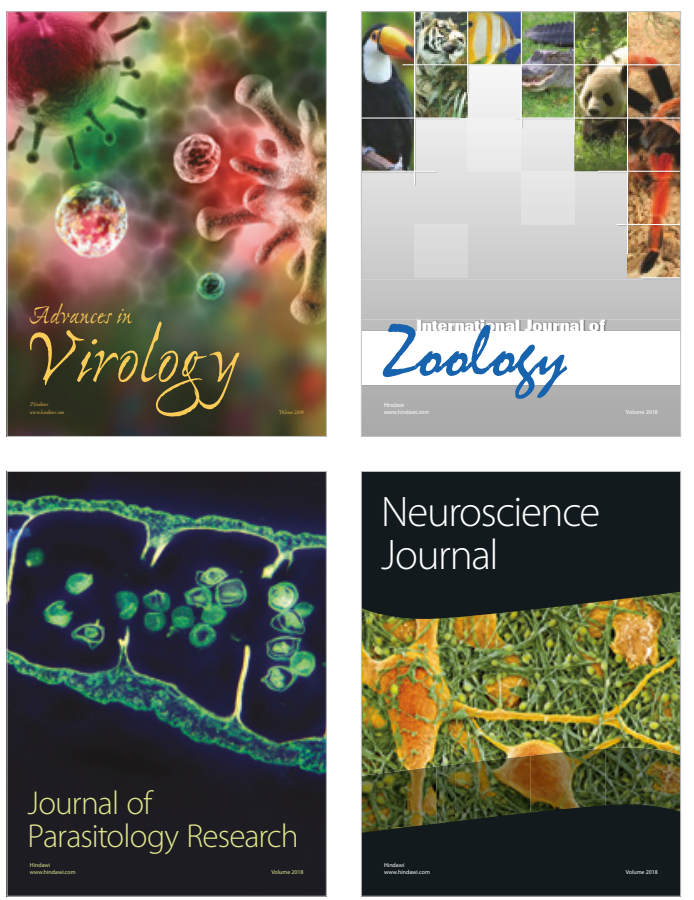
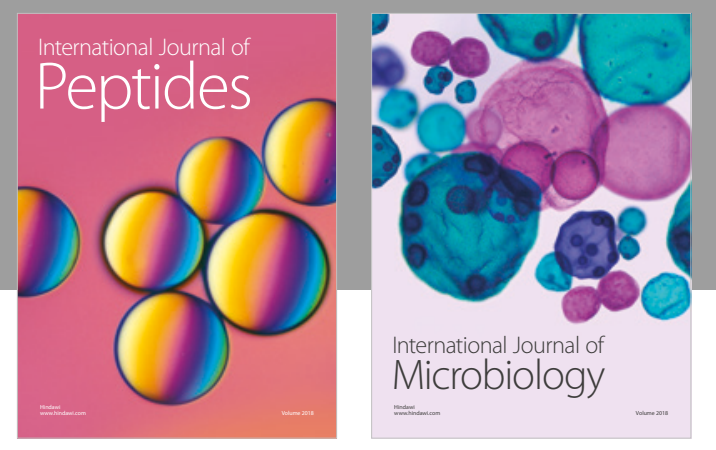

nternational Journal of Microbiology
Journal of
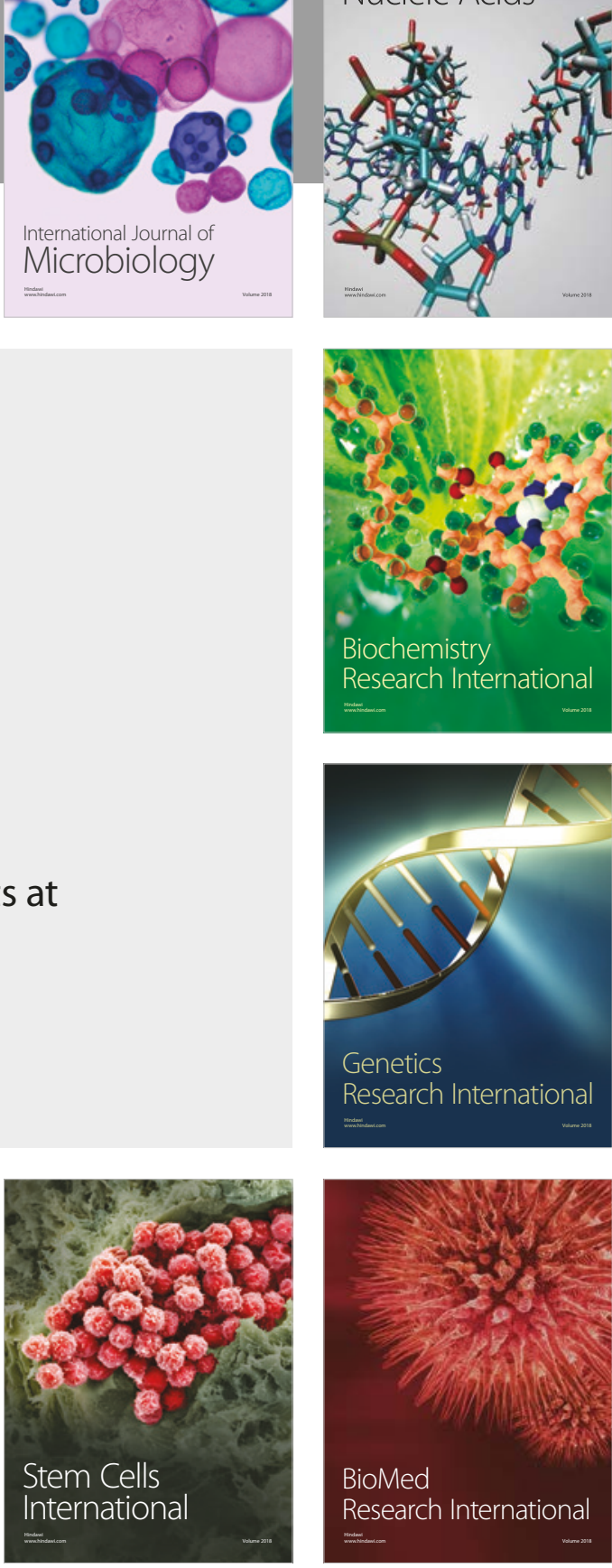
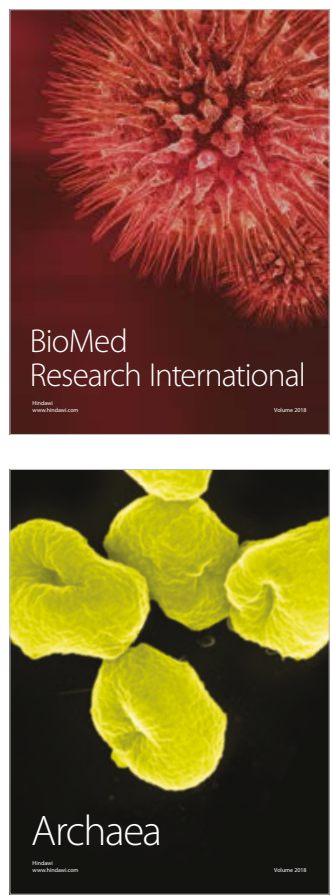